\title{
Water in the city. The development of permeable surfaces in urban areas
}

\author{
Dorota Jopek ${ }^{1, *}$ \\ ${ }^{1}$ Dept. of Regional Economy, Cracow University of Economics, 24 Rakowicka St., Cracow, Poland
}

\begin{abstract}
In the coming years, cities will face new challenges from a rapidly changing climate. Many physical infrastructure and building projects will face new or more severe risks from extreme flooding, precipitation and heat events. At the same time, environmental conditions are also projected to change, posing chronic hazards as average yearly temperatures rise. The natural cycle of water circulation in contemporary cities is often very disturbed as a result of improper management of space. The necessity to protect the natural environment, and in particular respect for water rights, in the face of climate change and constant pressure of urbanization requires a radical change in the approach to rainwater and surface water management in Polish cities. It is necessary to improve the integration of spatial planning with water management in many areas. The purpose of this research is to determine the effective role of space management processes to provide permeable surfaces in the urban areas as an important element of the system of rainwater management. The article will present an analysis of the possibilities of increasing the absorptivity of the areas in selected areas of Cracow.
\end{abstract}

\section{Introduction}

From the beginning of a settlement, the relationship between the city and water was a very important determinant of the development of urban areas. Benefits resulting from the location of a city in the vicinity of water were initially associated with defence, the possibility of using it as a transport route, for industrial and agricultural uses, and the availability of drinking water. It was only later that water started to be perceived as an attractive part of both the natural and built-up environment and one of the elements crystallizing the city structure. Now, among others, water is associated with an appreciation of its role in shaping public spaces, especially of its recreational character. Also, its cultural and natural values are very important in the process of building the image of the city.

In contemporary cities, the image is not only created based on the urban tissue, but also on the natural features of the urban landscape. Water creates a resource of the natural environment, which as a result of urban transformations can be the subject of degradation or development. The use of water in urban development processes is related to the implementation of the policy of balancing the needs of the natural and urbanized

* Corresponding author: jopekd@uek.krakow.pl 
environment. The management of water areas in a city is a topic taken up in many aspects, for example, the management of rainwater in urban areas.

The purpose of this research is to determine the effective role of space management processes to provide permeable surfaces in urban areas as an important element of the system of rainwater management. The article will present an analysis of the possibilities of increasing the absorptivity of the areas in selected areas of Cracow.

\section{Urbanization and the resiliency of cities}

The dynamics of development of contemporary cities, and the constantly increasing number of their inhabitants, generate large spatial and land use changes. As a result, new investments in various sectors of the economy, create a high demand for premises such as residential, office, service, commercial, production or transport use. Also, the effects of the changing climate, especially the increase of the temperature, frequency and intensity of extreme phenomena, have become big challenges for cities. Among the progressing climate changes, there are many elements related to natural disasters, such as floods, droughts, fires, heat waves and rainstorms.

Cities have changed dramatically in recent years. Rapid urbanization has led to the loss of greenery in cities and created various environmental issues. Rainwater has nowhere to go to infiltrate since almost everything is paved because of the growing number of roads, sidewalks, squares, parking lots, and the density of residential and service buildings. It significantly changes runoff efficiency, so adequate systems must be created to avoid the drowning retention of rainwater. Increasing the amount of impervious surfaces in cities requires the coordination of this process in planning, economic and social aspects. However, the process of urban structure development, which is often associated with increasing impervious surfaces, must be based on a comprehensive policy of spatial development of the city taking into account the principles of sustainable management of rainwater.

The increasingly impervious surface areas in cities, which is the subject of the presented analysis, should be discussed in relation to the effects of the rapid storm waters that overflow along surfaces. Designing effective solutions to manage the quantities and qualities of stormwater are tasks not only for environmental engineers but also for urban planners.

\subsection{Green and blue infrastructure in the spatial planning process}

Green infrastructure, as defined in the Communication of the European Commission is a tool for providing ecological, economic and social benefits through natural solutions. It helps us to understand the value of the benefits that nature provides to human society and to mobilise investments to sustain and enhance them. Green Infrastructure is based on the principle that protecting and enhancing nature and natural processes, and the many benefits human society gets from nature, are consciously integrated into spatial planning and territorial development [1.].

It is also a network of natural areas, semi-natural areas and green areas, which provides ecosystem services that can improve the well-being and quality of life of people. A green infrastructure can create a variety of green areas. They can occur in the form of natural elements of the natural environment (e.g. watercourses, meadows, wetlands) and elements designed by man (e.g. parks, gardens, green roofs, etc.). Building green infrastructure must therefore be conducted not only in the creation of new elements, like in processes of revitalization, but also the reclamation or restoration of the city's connections with it natural environment. The benefits of the sustainable water management of precipitation and the 
proper development of surface waters are indisputable at many levels: environmental, social and economic. Sustainable water management is not only a need in contemporary cities, but above all a necessity. Threats of flooding and the shortage of drinking water, results in an increase in the city's operating costs, the loss of resources in the natural environment, and the disruption of natural systems are frequent problems experienced by many cities. The strategies implemented in many countries assume increasing the retention capacity of river valleys and entire catchments as well as the better integration of urban planning with sustainable water management, both in the areas of urban waterfronts (direct protection against flood risks), and in remote areas from coastal zones (increasing rainwater retention to reduce flood risks in lower areas). In Poland, the aims and directions of the state spatial policy emphasizes that urbanization processes cannot disturb the rational proportions between biologically active and built-up areas [3] and the rational use of natural resources.

In terms of spatial aspects, both issues should be included in urban development as well as city planning by a proper formulation of the principles of rainwater management in the provisions of the local plans. Urban planning and planning issues should concern, among others :

- introducing rules for increasing the retention areas in the areas of existing buildings. The scope of these activities may include, for example, the creation of green roofs or green walls,

- increasing the retention area in the areas of existing buildings,

- providing the principles of the sustainable management of rainwater coming from the surface of road belts,

- using water-permeable surface technology when creating hardened surfaces, which allows maintaining the proper water level on the ground,

- implementing projects within the framework of the environmental revitalization of cities, like improving the quality of the natural environment in the protection of open areas for the city, improving the quality of water resources and greenery in terms of both urban protection of biodiversity, creating solutions to eliminate adverse climate change and the needs of recreation and the health of residents

- primarily taking into account the maximum area indicators of impermeable or building surfaces and other types of investment and minimum biologically active area

- planning documents should contain more detailed guidelines and rules for the development of flood risk areas and include the obligatory drawing up of small retention programs or extending the scope in catchment management

- taking into account the water and environment objectives in the study of conditions and directions of spatial management of the community / city and transposing the guidelines on the provisions of local spatial development plans and decisions on building conditions.

\subsection{Biologically active area (BAA)}

Green areas constitute a biologically active surface which is the permeable surface able to help manage rainfall within built-up areas. Keeping the right balance between green, permeable and built-up areas is particularly important in those with compact buildings. As per legal regulation [2.], the biologically active area is an area with an arranged surface in a way that ensures the natural vegetation of plants and the retention of rainwater, as well as $50 \%$ of the surface of terraces and flat roofs with such a surface and other surfaces providing natural vegetation with an area of not less than $10 \mathrm{~m} 2$, and surface water in this area. The term a biologically active area is related to the term of green areas. According to the same regulation, green areas are areas covered with vegetation with a technical infrastructure and functionally connected buildings, located within the boundaries of a 
village with compact buildings or cities, performing aesthetic, recreational or health functions, in particular parks, green spaces, promenades, boulevards, botanical gardens, zoological, historic gardens as well as cemeteries, and greenery accompanying streets, squares, historic fortifications, buildings, landfills, airports, railway and industrial facilities. The most effective mitigation of the negative transformations of the natural water cycle in the city takes place in large biologically active areas having a diversified species structure with a predominance of trees. Most multilayer systems (e.g. forest parks) provide a valuable biological diversity and a high activity of ecological processes. The less efficient forms of city greenery are lawns located along busy streets, but by proper development of this area they can also become the most important element of the system [6.]. It should be emphasized that the proper water management of rainfall in cities is very important from the point of view of the living conditions of residents and sustainable urban development, including the rational assurance management of water resources and environmental protection requirements.

\subsection{Rainwater Management in Urban Areas}

Cities, in different ways, try to counteract the negative effects of urbanization and climate change. One of them is the problem related to the water management of rainwater and snowmelt. As previously mentioned, the share of unpaved areas systematically decreases while at the same time destroys the natural network hydrographic. As a result, there is a need to develop a rainfall sewage system from sealed areas, and additionally to limit the reduction of green areas, and provide the addition solution to the problem of rainwater which is called a little retention. Actions taken to increase the share of biological areas active in urbanized areas are conducted on several levels. One of them is the protection and development of green areas associated with the occurrence of water surface, for example, ponds in park areas. These types of tanks on the one hand, diversify the landscape and, at the same time, the right type of development are a mainstay for the valuable species of flora and fauna. It is possible even if such a tank is used for commercial purposes, or recreational activities. The retention of water in tanks allowing for the storage of resources of disposable water enables their trouble-free operation over the time of the occurrence of extreme climate events. On the scale of the entire city, the green areas that enable it play a large role in the retention of rainwater or snowmelt. You can use these absorbent soils to manage rainwater and distribute it on an unpaved surface plot. These are areas of forests, parks, allotments, green areas and greenery housing estate or home gardens. They also often form a network of the system nature, which can also be used in both aspects of the behavior of natural continuity and connections of public spaces (eg river parks). The process of improving rainwater management in urban areas is related to bluegreen infrastructure, a set of activities aimed at maintaining or increasing the share of biologically active areas in the total area of the city. One of its elements are solutions consisting in the installation of greenery on buildings, i.e. green roofs and vertical gardens. They are of great importance for reducing the amount of rainwater that is burdened with rainwater or combined sewage systems. This results in additional benefits resulting from an increase in the share of the biologically active area of the developed lot, which in turn allows the expansion of the building development area. Due to the additional vegetation load, it is necessary to take this into account during the construction calculations of buildings, and therefore the adaptation of existing buildings is unlikely to be considered. 


\section{Case of Cracow. Analysis of the biologically active areas}

Cracow as one of the largest cities in Poland and is subjected to very high investment pressure. Due to the fact that the city is both a large academic centre and a tourist and business services centre, it results in a high demand for residential, office, retail and service space that generates dynamics in the construction market. Changes also occur in already built-up areas, where often the changes of the use of buildings create new sites arrangement. For example, in the areas of the oldest parts of Krakow it is common to change the use of the building from residential to commercial, like offices or services. These new features most often require a greater demand for parking spaces, which are located in backyards and inside the blocks at the expense of existing green areas.

Table 1. Analysis of the existing and planned biologically active area (example).

\begin{tabular}{|c|c|c|c|}
\hline \multicolumn{2}{|c|}{$\begin{array}{l}\text { Example 1: Block A - Dietla Ave., } \\
\text { Orzeszkowa St., Paulińska St., } \\
\text { Kordeckiego St. }\end{array}$} & \multicolumn{2}{|c|}{$\begin{array}{l}\text { Example 2: Block B - Wolnica Square, Wawrzyńca } \\
\text { St., Gazowa St., Bocheńska St. }\end{array}$} \\
\hline $\begin{array}{l}\text { Fig. Analyzed block } \\
\text { A1, Source: author }\end{array}$ & 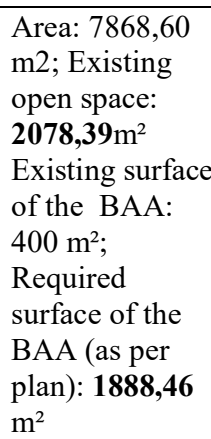 & $\begin{array}{l}\text { Fig. Analyzed block A2, } \\
\text { Source: author }\end{array}$ & $\begin{array}{l}\text { Area: } 9871,22 \mathrm{~m}^{2} \\
\text { Existing open space: } \\
\text { 3785,31 } \mathrm{m}^{2} \text {; Existing } \\
\text { surface of BAA: } 1900 \\
\mathrm{~m}^{2} \text {; Required surface } \\
\text { of the BAA (as per } \\
\text { plan): W/U33: } 1991,74 \\
\mathrm{~m} 2 ; \text { ZPz.18: } 1572,3 \\
\mathrm{~m}^{2} \text {. Total per block: } \\
\mathbf{2 9 3 5 , 1 2}^{2}\end{array}$ \\
\hline $\begin{array}{l}\text { Fig. Part of the } \\
\text { master plan } \\
\text { „Kazimierz" } \\
\text { Source: } \\
\text { www.bip.krakow.pl }\end{array}$ & $\begin{array}{l}\text { The area of } \\
\text { residential and } \\
\text { service } \\
\text { buildings is } \\
\text { designated as a } \\
\text { zone MW/U.52, } \\
\text { min. indicator } \\
\text { of the BAA: } \\
24 \% \text {. }\end{array}$ & $\begin{array}{l}\text { KP.6 } \\
\text { Fig. Part of the master plan } \\
\text { "Kazimierz” } \\
\text { Source: www.bip.krakow.pl }\end{array}$ & $\begin{array}{l}\text { The area of residential } \\
\text { and service buildings is } \\
\text { designated as a zone } \\
\text { MW/U.33, min. } \\
\text { indicator of the BAA: } \\
24 \% \text {. In the center of } \\
\text { the block: the green } \\
\text { area is delimitated } \\
\text { ZPz.18 - min. indicator } \\
\text { of the BAA: } 60 \% \text {. }\end{array}$ \\
\hline & & & Source: author \\
\hline
\end{tabular}

The subject of the conducted research concerns the analysis of the existing biologically active area in selected urban blocks. The analysis in done in comparison with the planned area of greenery, expressed by the indicators included in the provisions of the local spatial management plans (also called a local development plan). The main goal of the research is to determine whether the indicators included in the arrangements of planning documents have a chance for their implementation. For the purpose of the research, over fifty blocks located within three structural urban areas [5] were selected. The designated areas are called A, B and E. Area A includes the city centre and the area of the 2nd beltway, which can be divided into two parts. The first of them is a historical centre (area inscribed on the UNESCO list), the second includes the first city bypass with the areas located between the 
historic centre and the 2 nd city beltway. Area B includes a downtown ring with the areas located within the borders of the 3rd beltway of Cracow. Area E, however, is the area of the urban complex of the oldest part of Nowa Huta (a district of Cracow) together with the adjacent landscape areas. The main research methods are spatial data analysis, surveying maps, planning documents and field tests.

In the conducted analysis, the provisions of the local development plan regarding the value of an indicator of the biologically active area are verified according to its existing value. Therefore, the basis of the blocks selection is the local development plan effected in their area. Additionally, another purpose was that the analyzed blocks are located in various urban areas of Cracow with different spatial arrangements.

Table 1 presents an example of the card information provided for each of analysed blocks. The information includes: the location of the block, described by the surrounding streets, the calculation of the total area of the block with a division of the different uses (if applicable in the local plan), the amount of existing open space, the existing biologically active area, the required minimum area of the biologically active area (by the indicators in the local plan). The card also includes a schematic of the analyzed areas (build-up, open and green), and a part of the map of the local plan. All the blocks are also documented by photographs (not included in this paper).

Based on the card information, the final results are presented in a table allowing for a clear summary of the obtained indicators (table 2). The results showed (due to limited volume of this paper, table 2 presents a fragment of a simplified pledge of collected data) that the greatest discrepancies between the indicators included in planning documents and the indicators of the existing condition appear in the areas of compact development (area A). With the existing lot development of most of analyzed blocks, achieving the planned level of values of indicators is very difficult in practice. The analyzed blocks, located in the $\mathrm{B}$ areas are characterized by a smaller difference between the size of the existing permeable area and its values defined in the local plan. Although the disproportion in most cases was much smaller, it is not satisfactory and, according to the author, requires action to increase the permeable areas. In most of the analyzed blocks, alternative solutions in the form of green walls and roofs had to be applied in order to improve overall condition and amount of green areas. However, it should be taken into account, that the implementation of the latter may be difficult due to existing roof constructions and the possibility of their additional load as well as the often too large slope of their roof. Additionally, in areas under conservation protection, both the use of green roofs and walls should be approved by the conservator. Due to these restrictions, it should be assumed that possible actions may concern only buildings located inside the blocks, i.e. outbuildings. Another solution that should be used to increase the permeability of the areas is the replacement of hardened surfaces with the use of rainwater permeable materials. However, in the case of impermeable surfaces, a key role is played by designing appropriate inheritances that ensure adequate water run-off to nearby retention ponds or other features.

An interesting analyzed example is area E. As mentioned above, this is an area of the urban complex of the oldest part of Nowa Huta. One of the inspirations for urbanists who designed that area in the 1950s, was Howard's idea of Garden City. In addition, it is important to mention, that this area, even though it is recognized as a protected area with a high urban value, for many years has been considered as a degraded area with mostly lowincome inhabitants. Therefore, the development of this area was very limited, also in the aspect of increasing the impervious surface. In all of the blocks analyzed in area E, the existing biologically active area was equal or almost equal to the indicators defined in the local plan. 
Table 2. Part of the data collected and analysed for the selected blocks in Cracow.

\begin{tabular}{|c|c|c|c|c|c|c|c|c|c|}
\hline \multirow[b]{2}{*}{$\begin{array}{c}\text { Sy } \\
\mathrm{mb} \\
\mathrm{ol}\end{array}$} & \multicolumn{9}{|c|}{ Block analysis } \\
\hline & $\begin{array}{l}\text { Total } \\
\text { area } \\
{[\mathrm{m} 2]}\end{array}$ & $\begin{array}{c}\text { Exist. } \\
\text { Build-up } \\
\text { area } \\
{[\mathrm{m} 2]}\end{array}$ & $\begin{array}{l}\text { Exist. } \\
\text { Open } \\
\text { space } \\
{[\mathrm{m} 2]}\end{array}$ & $\begin{array}{c}\text { Exist. } \\
\text { BAA** }^{*} \\
{[\mathrm{~m} 2]}\end{array}$ & $\begin{array}{c}\% \\
\text { BAA } \\
* \\
{[\%]}\end{array}$ & $\begin{array}{l}\text { Name of } \\
\text { Mpzp }\end{array}$ & $\begin{array}{c}\text { Indicat } \\
\text { or } \\
\text { Mpzp* } \\
*\end{array}$ & $\begin{array}{l}\text { Req. } \\
\text { BAA* } \\
{[\mathrm{m} 2]}\end{array}$ & $\begin{array}{c}\text { Balanc } \\
\mathrm{e} \\
{[\mathrm{m} 2]}\end{array}$ \\
\hline A1 & 7868,6 & 5790,2 & 2078,4 & 400 & 5 & $\begin{array}{c}\text { Kazimier } \\
\text { z }\end{array}$ & $\begin{array}{c}\mathrm{MW} / \mathrm{U} \\
.52 \\
24 \%\end{array}$ & & \\
\hline A2 & 9871,2 & 6085,9 & 3785,3 & 1900 & 19,1 & $\begin{array}{c}\text { Kazimier } \\
\mathrm{z}\end{array}$ & $\begin{array}{c}\mathrm{MW} / \mathrm{U} \\
.33 \\
24 \%\end{array}$ & & \\
\hline A3 & 6149,5 & 4986,0 & 1163,5 & 172,7 & 3 & $\begin{array}{c}\text { Stare } \\
\text { Podgórze }\end{array}$ & $5 \%$ & $\begin{array}{c}(-) \\
307,4 \\
\end{array}$ & $\begin{array}{c}134,77 \\
(2 \%) \\
\end{array}$ \\
\hline B1 & 14270 & 8173,3 & 6096,5 & 1598,6 & 11 & $\begin{array}{c}\text { Rynek } \\
\text { Krowode } \\
\text { rski }\end{array}$ & $24 \%$ & $\begin{array}{c}(-) \\
3424,7\end{array}$ & $\begin{array}{c}1826,1 \\
5 \\
(13 \%)\end{array}$ \\
\hline B2 & 14063 & 4720,0 & 9343 & 5735,7 & 40,7 & $\begin{array}{c}\text { Osiedle } \\
\text { Oficerski } \\
\mathrm{e} \\
\end{array}$ & $60 \%$ & $\begin{array}{c}(-) \\
8437,8\end{array}$ & $\begin{array}{c}2702,1 \\
(19,3 \% \\
)\end{array}$ \\
\hline E1 & 39005 & 8629,9 & 30375 & 21572,9 & 55 & $\begin{array}{c}\text { Centrum } \\
\text { Nowej } \\
\text { Huty }\end{array}$ & $45 \%$ & $\begin{array}{c}(+) \\
21573\end{array}$ & $\begin{array}{l}4020,6 \\
(10 \%)\end{array}$ \\
\hline E2 & $\begin{array}{l}23561 \\
13962\end{array}$ & $\begin{array}{l}10125 \\
3133,5\end{array}$ & $\begin{array}{l}13436 \\
10829\end{array}$ & $\begin{array}{c}4720,2 \\
6980\end{array}$ & $\begin{array}{l}20 \\
50\end{array}$ & $\begin{array}{c}\text { Centrum } \\
\text { Nowej } \\
\text { Huty }\end{array}$ & $\begin{array}{c}\text { MWs/ } \\
\text { U8.120 } \\
\% \\
\text { MWn } \\
8.1 \\
50 \% \\
\end{array}$ & $\begin{array}{r}4723,2 \\
6981\end{array}$ & $\begin{array}{c} \pm 3 \\
(20 \%) \\
\pm 1 \\
(50 \%\end{array}$ \\
\hline $\begin{array}{l}* \mathrm{Bi} \\
* * \mathrm{~N}\end{array}$ & $\begin{array}{l}\text { cally } \\
\text { - Loc }\end{array}$ & $\begin{array}{l}\text { area } \\
\text { tial Ma }\end{array}$ & mot & & & & e: autl & & \\
\hline
\end{tabular}

The assumptions of the study have been formulated in order to analyse the feasibility of achieving the planned values (according to local plans) of minimum biologically active area indicators in existing blocks in areas with the highest building ratio. The results achieved in this research are the starting point for the diagnosis of the individual city areas in terms of the number of existing permeable areas. Also, this is the first stage of the analysis of the possibility of increasing the biologically active surface in urban built-up areas in order to improve their water retention.

\section{Conclusions}

Conclusions defined on the basis of the obtained analysis results are as follows:

1. each quarter requires an individual analysis to determine the possibility of increasing permeable surfaces with an indication of specific solutions and their technical specifications.

2. it is necessary to create a catalogue of solutions that can be used in individual cases. The catalogue should include detailed information on the retention capacity of the applied solutions of green walls or green roofs.

3. management of rainwater as a complex system in urban areas is a necessity. Blocks shall be treated as puzzles of the composition, one element of the entire system. In many of the analysed quarters, there is a tendency to enlarge impervious areas usually as mentioned above, most often associated with the desire to provide additional parking spaces. Often, these actions are done 
unintentionally, without taking into account the indicators in the local development plans. Therefore, it is necessary to undertake actions leading to monitoring the implementation of transformation projects of the lot development.

\section{References}

1. Communication from the Commission to the European Parliament, the Council, the European Economic and Social Committee and the Committee of the Regions Green Infrastructure (GI) — Enhancing Europe's Natural Capital /* COM/2013/0249 final, http://ec.europa.eu/environment/nature/ecosystems/strategy/index_en.html

2. National Strategy of Regional Development 2010-2020: Regions, Cities, Rural Areas, Source: http://www.espon-usespon.eu/library,national-regional-development-strategy2010-2020-regions-cities-rural-areas-nsrd-f7da

3. Regulation of the Minister of Infrastructure on the technical conditions which should be met by buildings and their location (Dz.U. 2017 poz. 2285) http://prawo.sejm.gov.pl/isap.nsf/DocDetails.xsp?id=WDU20170002285

4. Gawlik, B.M., Easton, P., Koop, S., Van Leeuwen, K., Elelman, R., (eds.), 2017, Urban Water Atlas for Europe. European Commission, Publications Office of the European Union, Luxembourg. 160 pp.

5. Study of the Conditions and Directions of the Spatial Management of a Cracow Commune, nr CXII/1700/14.07.2014, https://www.bip.krakow.pl/?id=48.

6. Lejcuś K. and others, Catalogue of good practices - principles of the sustainable management of waters rainfall from the surface of road lanes

https://www.wroclaw.pl/srodowisko/files/dokumenty/8811/Katalog\%20Dobrych\%20P raktyk\%20-\%20drogi.pdf 